\title{
Production of Agglomerates, Composite Materials, and Seed Coatings from Tannery Waste as New Methods for Its Management
}

\author{
Katarzyna Ławińska
}

check for updates

Citation: Ławińska, K. Production of Agglomerates, Composite Materials, and Seed Coatings from Tannery Waste as New Methods for Its Management. Materials 2021, 14, 6695. https://doi.org/10.3390/ma14216695

Academic Editors: Carmen Gaidau and Anna Bacardit Dalmases

Received: 11 October 2021

Accepted: 4 November 2021

Published: 6 November 2021

Publisher's Note: MDPI stays neutral with regard to jurisdictional claims in published maps and institutional affiliations.

Copyright: (C) 2021 by the author. Licensee MDPI, Basel, Switzerland. This article is an open access article distributed under the terms and conditions of the Creative Commons Attribution (CC BY) license (https:/ / creativecommons.org/licenses/by/ $4.0 /)$.
Łukasiewicz Research Network-Institute of Leather Industry, Zgierska 73, 91-463 Lodz, Poland; katarzyna.lawinska@ips.lukasiewicz.gov.pl

\begin{abstract}
This paper presents methods for managing waste produced by the leather industry, including tanning shavings derived from chrome tanning technologies and collagen preparations. Shavings were classified according to their shape (in accordance with Zingg's shape classification). The content of individual elements was determined, together with the content of volatile organic compounds. Two new products were developed as part of the completed works: agglomerates (methods of nonpressure granulation) and composite materials were produced on the basis of tanning shavings and mineral fillers. Young's modulus values classify these composite materials in the group of polymers and certain materials from the group of elastomers. A method for seed coating (on the example of legumes and rape) was also developed using a disc granulator, including collagen preparations in one of the layers as a solution for preventing the effects of droughts (biostimulant). The analyses of selected properties of the new products confirm the wide possible application of waste shavings and collagen preparations in a circular economy, especially in the construction, packaging, and agricultural sectors.
\end{abstract}

Keywords: tanning shavings; waste collagen; composite; granulation; biostimulants

\section{Introduction}

Leather is the tanning sector's main output and an intermediate industrial product, with applications in downstream sectors of the consumer goods industry (such as footwear, clothes, furniture, and the automotive sector). Waste generated by the leather industry, due to its composition, may be used as a raw material for manufacturing new economic products, thus ensuring sustainable and eco-friendly industrial practices. Solid leather waste can be considered a composite material that is highly structured and connected with collagen fibers [1]. Different forms of solid waste are produced during rawhide processing, including tannery fleshing waste (TFW) (viscous and biodegradable products including $8 \%$ salt, $8 \%$ collagen, $4 \%$ fats, and $80 \%$ water [2]), chrome shavings, chrome splits and buffing dust, skin trimmings, and hair [3]. In order to efficiently manage waste, the TFW manufacturing residue has been used, for example, for biogas [4], biodiesel [2,5,6], or biofuels and economic biochar $[7,8]$ with potential application as a soil biofertilizer or as a low-cost bioabsorbent. The authors of papers [9-11] pointed to the use of leather shavings as alternative adsorbents, e.g., for the treatment of wastewater containing dyes.

In adsorbent materials, in order to remove volatile organic compound (VOC) pollutants, microporous activated carbons [12-16] were obtained from vegetable-tanned leather waste (shavings, buffing dust) [17]. In study [18], the ability of chrome shavings to remove motor oils, oily wastes, and hydrocarbons from water was studied. Solid residue pyrolysis can be adopted as an innovative solution by tanners and leather producers. Thermal decomposition of leather waste begins at $80{ }^{\circ} \mathrm{C}$, and its maximum is $325^{\circ} \mathrm{C}$ [19]. Paper [20] provided a strategy for the high-value use of chrome shavings (by pyrolyzing) and a 
practical method for the removal of antibiotics. Study [21] provided basic data for the determination of pyrolysis temperatures of chrome-tanned leather shavings targeting different products. Moreover, the authors of papers [22-26] developed a model for simulating and predicting the pyrolysis behavior of chrome shavings. A pretreatment can increase the feasibility of producing energy with chromium leather waste [27] and can reduce the costs of energy consumption, waste disposal, eliminate solid waste, and reduce greenhouse gas emissions from microbiological degradation of tannery waste [28,29]. The removal and recovery of heavy metals from tannery sludge subjected to a plasma pyro-gasification process was described in [30]. The gasification of biochar derived from tanning shavings resulted in two main products: a hydrogen-rich syngas, which has applications such as electricity generation and chemical production, and a chromium-rich ash, which can potentially be utilized, e.g., in stainless-steel manufacturing processes [31]. Olejnik, in his work [32-34], focused on the different aspects of process efficiency and reducing the technology impact on the environment, with reference to economy and pollutant interaction.

Chromium is a valuable resource, and its reuse is economical and environmentally feasible [35]. Chrome is the most successful tanning agent used in leather tanning processes (due to its ability to produce leather with attributes desirable for high-quality leather: hydrothermal stability, better dyeing characteristics and softness). Chromium recovered from chrome-tanned leather shavings showed the possibility of producing pigments for paints and paint coats [36]. Protein from chrome shavings may be reused after chemical modification as a replacement for commercial retanning products [37]. Moreover, the collagen hydrolysate obtained from chromed shavings after alkali and enzymatic hydrolysis is suitable as a component of leather finishing coatings (as a 5\% addition) [38]. In study [39], a protein-based product was developed from raw trimming waste and used in a chrome tanning process to enhance the exhaustion level of chromium.

Paper [40] highlights the emerging body of knowledge and research on chromium minimization, recycling and/or reuse of chromium waste to make tanneries safer for people and more eco-friendly. A scheme for the total control of chromium in the leather industry was designed in paper [41]. Long et al. [42] described a method for recovering $\mathrm{Cr}$ (VI) from tannery sludge and chrome-tanned leather shavings. There is also tanning technology based on wet white and a combination method, which involves the mixing of tanning agents $[43,44]$. Leather waste is disposed of in landfills; however, the composting of leather with food waste is a promising alternative to landfills [45].

In line with environmental awareness, the idea of a circular economy, and an increased interest in eco-friendly technologies, the objective of this study is to present methods explored by the Łukasiewicz Research Network, Institute of Leather Industry, to minimize the production and management of waste from the leather industry. So far, natural leather is still the best material for various products, especially footwear. The presented actions in terms of processing selected waste from the leather industry are consistent with the European Green Deal, which is a set of policy initiatives aimed at securing the sustainable economy of the EU.

\section{Materials and Methods}

This paper describes the use of unit processes in methods of processing waste generated by the leather industry on the basis of chromium tanning shavings and waste collagen preparations for the purpose of their reuse. The granulometric composition of shavings was determined on the basis of screen analysis [46,47], taking into account sieve hole blocking [48-51]. Zingg's classification was used for analyzing the shavings shape (using a KAMIKA Instruments analyzer, Warsa, Poland). On the basis of this classification, four basic shapes of grains were differentiated: disc-shaped, spherical, bladed, and rod-like. The method of a falling grain scanning was used in a three-dimensional measurement (two dimensions were obtained on the basis of optical measurements of transducers, while the third dimension was determined based on how many times each grain was scanned). The chemical composition of tanning shavings samples in terms of their content of selected 
elements (metals) was determined using inductively coupled plasma-optical emission spectrometry (ICP-OES) [52]. In these tests, shavings samples $(0.2 \mathrm{~g})$ were placed in a Teflon vessel, and $6 \mathrm{~cm}^{3}$ of $\mathrm{HNO}_{3}(65 \%)$ were added. Next, they were mineralized using the Magnum II (ERTEC-POLAND Edward Reszke, Wroclaw, Poland) microwave reactor in 3 cycles totaling $20 \mathrm{~min}$, at $300{ }^{\circ} \mathrm{C}$ and at pressure rising to 45 bar. Clear digest solutions were quantitatively transferred to $25 \mathrm{~cm}^{3}$ flasks, and demineralized water was added. All of the tested samples were analyzed using the inductively coupled plasma-atomic emission spectrometry with the ICP-OES 5110 spectrometer (Agilent, Santa Clara, CA, USA). The content of the tested elements in the shavings samples was read using calibration curves developed on the basis of the individual metal models.

The content of volatile organic compounds (VOC) was determined using the gas chromatography method with a mass detector (GC/MS/HS) at $150^{\circ} \mathrm{C}$. The preparation method involved the direct heating of a sample placed in a vial (sample mass of $0.2 \mathrm{~g}$ ) in the chromatograph furnace; then, the emitted compounds were chromatographically separated. Samples were analyzed using the 2030 Nexis GC (Shimadzu Corporation, Kyoto, Japan) chromatograph fitted with MS GCMS-QP2020 (Shimadzu Corporation, Kyoto, Japan) and a headspace-type AOC-20i autosampler (Shimadzu Corporation, Kyoto, Japan). A chromatography column dedicated for the separation and quantification of VOC, ZB624plus (Phenomenex Companies Worldwide, Torrance, CA, USA) was used. The furnace temperature was initially maintained at $40{ }^{\circ} \mathrm{C}$ for $1 \mathrm{~min}$ and then increased by $10^{\circ} \mathrm{C} \cdot \mathrm{min}^{-1}$ to $150^{\circ} \mathrm{C}$. The injection volume was $1.0 \mathrm{~cm}^{3}$, while the separation ratio was 1:10. The model VOC solution (mixture) was purchased from Sigma-Aldrich (Taufkirchen, Germany).

As part of the research, new composite materials were produced, containing $60 \%$ characterized tanning shavings and $40 \%$ adhesive medium (four types were used: a homopolymer that is a water dispersion of polyvinyl acetate, modified animal-derived gelatin glue, low-ammonia natural latex glue, and solvent-free colorless epoxy resin with a hardening agent) and a mineral filler: dolomite, kaolin, or bentonite (mineral content of $10 \%$ in relation to the shavings' mass) $[53,54]$. The mixture of all components was pressed in a hydraulic press at a constant pressure of $20 \mathrm{MPa}$ with the possibility of heating. The produced $280 \mathrm{~mm} \times 280 \mathrm{~mm}$ composites were dried in a laboratory drier at $25^{\circ} \mathrm{C}$ for $24 \mathrm{~h}$.

The produced composite materials were subjected to static tensile tests using a Zwick/Roell Z010 type testing machine (Zwick Roell Group, Ulm, Germany). Furthermore, for individual composite materials, their capacity for water absorption (absorbability) and for water release during the drying process was determined [50]. In view of the environmental aspect, analyses of the extracted chromium VI content (using the spectrophotometric method with 1,5-diphenylcarbazide) were performed.

Disc granulation [55-57] was selected for processing the shavings. The selected method made it possible to produce particles with a proper shape, dimensions, and physical and chemical properties. In addition, it is also a relatively easy to use, cost-efficient, and environmentally-friendly (waste-free) method that is effective for fine-grained materials. Wet materials may also be granulated using this method.

Non-pressure granulation methods were developed in order to give the shavings regular, spherical shapes and produce a loose regular deposit. A disc granulator (Lodz University of Technology, Lodz, Poland) $[58,59]$ and a vibrating disc granulator (Lodz University of Technology, Lodz, Poland) [60] were used for shavings granulation. Granulation was run until the majority of the fine-grained material was attached to the granules, ensuring that the agglomeration of granules did not occur (no coalescence phenomenon).

The following methods of producing granulated products were developed and tested. In the first method, a mixture of shavings and a fine-grained mineral material was granulated. Shavings were poured onto the granulator disc, and then, a dry mineral component was added in the form of powdered dolomite or gypsum. Granulation was carried out with simultaneous deposit drenching with a 50 or $75 \%$ soluble glass solution, using a hydraulic nozzle, in the form of drops of $0.01-0.5 \mathrm{~mm}$ in diameter [59]. The second method involved the soaking of the shavings with the binding liquid beforehand (shavings previously mixed 
with a water glass solution) and then granulating the wet pulp with the addition of a selected fine-grained mineral material (dolomite or gypsum). A $50 \%$ aqueous solution of water glass was used in the tests. The wet pulp was granulated on a rotating disc [60]. In the third method, a vibrating disc granulator was used. The addition of a $75 \%$ solution of sodium water glass (in the wet pulp), dolomite, and gypsum was applied. No binding liquid was added in the granulation process [60].

Waste collagen preparations were used as a component in the processes of producing seed coatings for the purpose of increasing the seeds' resistance to drought through improving moisture conditions at the stage of seed germination. The characteristics of the selected preparations are given in paper [61]. Disc granulation was also used to form coatings for the seeds of legumes (peas, broad bean, and soybean) and rape, on the basis of waste collagen preparations derived from alkaline hydrolysis [62,63]. The coating processes involved the use of natural additives facilitating germination, such as dolomite, chalk, and kaolin, as well as peat and soot. Furthermore, the environmental aspect (circular economy) was taken into account when selecting different types of the binding liquid; i.e., solutions of molasses (a waste product from the sugar industry) were used. The individual layers of the coating were formed in a specific order. The centrally placed seed was first coated with a layer of collagen hydrolysate or a solution of yellow dextrin and polyvinyl alcohol or a solution of molasses. The outer layer was a mineral additive. The impact of the coating composition on the initial growth of the plants was determined, above all, through the measurement of seedlings length. Growth was observed for 7 and 10 days.

\section{Results}

\subsection{Characteristics of Tanning Shavings}

The executed processes of tanning shavings screening showed that over $80 \%$ of their composition constituted grains of less than $8 \mathrm{~mm}$, with approximately $35 \%$ of those being below $1 \mathrm{~mm}$. Dry tanning shavings were characterized by very low bulk density that did not exceed $0.1 \mathrm{~g} / \mathrm{cm}^{3}$. The pore structure of the tested tanning shaving samples consisted mainly of mesopores and macropores (a relatively low BET (Brunauer-Emmett-Teller) specific surface area (SSA) in the range of $2.55-3.51 \mathrm{~m}^{2} / \mathrm{g}$ ) [60]. The results of the shavings shape analysis are given in Table 1 . The dominant shapes of shavings were spherical (70.14\%) and rod-like (23.77\%) (in accordance with Zingg's classification, Figure 1).

Table 1. Zingg's shavings shape classification.

\begin{tabular}{cc}
\hline Shape & Volume Fraction [\%] \\
\hline disc-shaped & $4.93 \pm 0.71$ \\
spherical & $70.14 \pm 1.02$ \\
bladed & $1.17 \pm 0.48$ \\
rod-like & $23.77 \pm 1.52$ \\
\hline
\end{tabular}

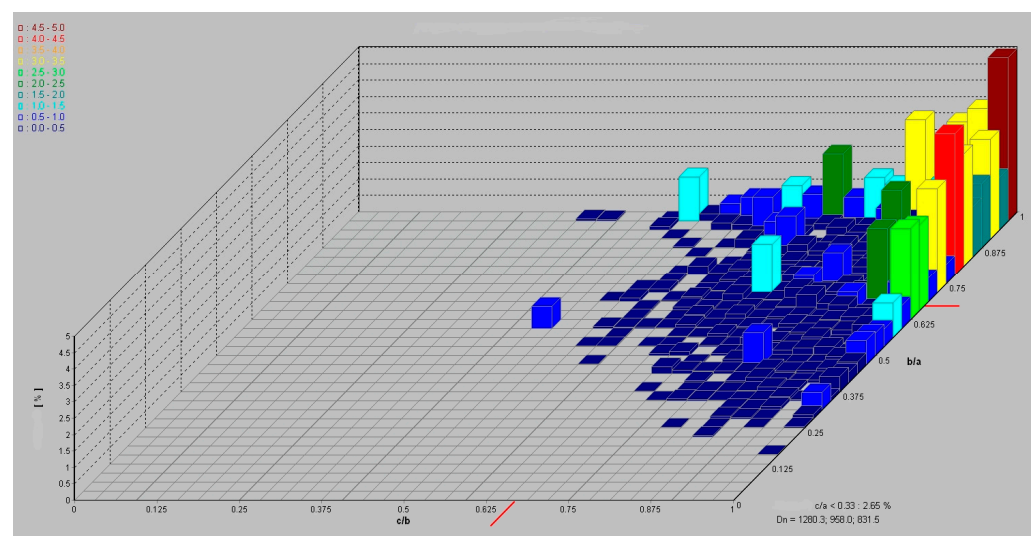

Figure 1. Shapes of shavings (in accordance with Zingg's classification). 
The results of the analysis of the tanning shaving samples' chemical composition are given in Table 2. The performed analyses showed that the tested waste contained significant amounts of elements. Tanning shavings can be considered useful waste in view of their elemental composition, due to a high content of $\mathrm{Ca}, \mathrm{Mg}$, $\mathrm{S}$, and $\mathrm{P}$ as a valuable source of macroelements and structural elements. The high content of $\mathrm{Ca}$, as well as $\mathrm{Na}$ in shavings, is also mentioned by the authors of paper [62]. The lack of, above all, $\mathrm{Pb}$ and $\mathrm{As}$ is important in view of the environmental aspect of the discussion.

Table 2. Chemical composition of shavings—content of elements in a sample ( $\mathrm{mg} / \mathrm{kg})$, ND—below the limit of detection.

\begin{tabular}{|c|c|}
\hline Element & Concentration $(\mathrm{mg} / \mathrm{kg})$ \\
\hline $\mathrm{Ag}$ & ND \\
\hline $\mathrm{Al}$ & 47.751 \\
\hline As & ND \\
\hline $\mathrm{Ba}$ & 1.697 \\
\hline $\mathrm{Bi}$ & ND \\
\hline $\mathrm{Ca}$ & 2056.97 \\
\hline $\mathrm{Cd}$ & ND \\
\hline Co & ND \\
\hline $\mathrm{Cr}$ & $10,371.6$ \\
\hline $\mathrm{Cu}$ & ND \\
\hline $\mathrm{Fe}$ & 490.561 \\
\hline $\mathrm{Ge}$ & ND \\
\hline $\mathrm{Hg}$ & ND \\
\hline $\mathrm{Mg}$ & 1380.45 \\
\hline $\mathrm{Mn}$ & 3.095 \\
\hline Mo & ND \\
\hline $\mathrm{Ni}$ & 4.687 \\
\hline $\mathrm{Pb}$ & ND \\
\hline $\mathrm{Sb}$ & ND \\
\hline Se & ND \\
\hline Sn & ND \\
\hline $\mathrm{Sr}$ & 1.193 \\
\hline $\mathrm{Ti}$ & ND \\
\hline $\mathrm{V}$ & ND \\
\hline $\mathrm{Zn}$ & 6.173 \\
\hline $\mathrm{Zr}$ & ND \\
\hline$S$ & 3231.75 \\
\hline $\mathrm{P}$ & 85.806 \\
\hline
\end{tabular}

The organic acids, preservatives, surfactants, and alkanes obtained as a result of the VOC analysis were the components of chemical preparations used during leather expedition and tanning (Table 3). Substances (e.g., hexadecanal) that are, according to the CLP Regulation (Regulation (Ec) No. 1272/2008 of the European Parliament and of the Council of 16 December 2008 on the classification, labelling, and packaging of substances and mixtures, amending and repealing Directives 67/548/EEC and 1999/45/EC, and amending Regulation (EC) No 1907/2006), classified as irritating or harmful to the environment, represented a small percentage of the analyzed waste.

\subsection{Composite Material Made of Waste Tanning Shavings and Mineral Fillers}

During the tests, new composite materials were produced based on fragmented collagen fibers contained in tanning shavings, derived from the processing of the wet blue leather semi-finished product. The described tests and their results prove that it is possible to produce composite materials based on waste tanning shavings and widely available mineral fillers and use them again in a closed cycle. As a result of the research, the optimal composition of a composite material made of collagen fibers derived from the leather industry waste and mineral fillers was determined. 
Table 3. Results of the VOC analysis.

\begin{tabular}{|c|c|}
\hline Substance Name & Percentage $(\%)$ \\
\hline 3,3-dichloropropine & 1.37 \\
\hline methylhydrazine & 0.29 \\
\hline formic acid & 2.11 \\
\hline methylphosphine/formic acid & 2.78 \\
\hline propylene glycol & 0.84 \\
\hline benzaldehyde & 1.04 \\
\hline carbitol & 0.38 \\
\hline benzosulfonosal & 8.75 \\
\hline 8-methylnonanoic acid & 0.32 \\
\hline 4-chloro-m-cresol & 16.11 \\
\hline 2-undecenal & 0.29 \\
\hline o-hydroxybifenyl & 43.57 \\
\hline tridecanal & 0.39 \\
\hline 2-(metylotio)-benzotiazol & 0.86 \\
\hline 2-octylfuran & 0.23 \\
\hline triethylene glycol monododecyl ether & 0.30 \\
\hline tetradecanal & 0.22 \\
\hline myristic acid & 0.37 \\
\hline hexadecanal & 2.41 \\
\hline pentadecanal & 0.26 \\
\hline palmitic acid methyl ester & 0.88 \\
\hline palitol acid & 0.35 \\
\hline pentadecanoic acid & 3.09 \\
\hline linoleic acid methyl ester & 0.41 \\
\hline methyl oleate & 7.91 \\
\hline 9-octadecenoic acid methyl ester & 2.51 \\
\hline methyl stearate & 0.41 \\
\hline cis-10-heptedecenoic acid & 0.63 \\
\hline other substances & 0.92 \\
\hline
\end{tabular}

When analyzing the values of the Young's moduli (Table 4) obtained for the produced composite materials, they can be classified within polymer foam (VLD, LD, and MD) and some materials from the elastomer group (IR, CR, and EVA), i.e., materials capable of reversible deformations under the impact of mechanical forces without the risk of losing the continuity of their structure, which significantly expands the potential areas of their application [48]. Summarizing [53,54], the type of the adhesive medium significantly impacts the ability to absorb and release water. Depending on the intended purpose of a given material, its ability to absorb water may be reduced or increased, as can its drying rate. In relation to environmental tests, composite materials made of collagen fibers derived from the leather industry waste and mineral fillers are safe to use, which is proven by the lack of $\mathrm{Cr}(\mathrm{VI})$ content.

Table 4. Value of the Young's moduli and density of the produced composite materials (average values).

\begin{tabular}{ccccc}
\hline & & \multicolumn{3}{c}{ Adhesive Medium } \\
\cline { 2 - 5 } Parameters & Homopolymer & Gelatin Glue & $\begin{array}{c}\text { Low-Ammonia } \\
\text { Natural Latex Glue }\end{array}$ & $\begin{array}{c}\text { Epoxy Resin with a } \\
\text { Hardening Agent }\end{array}$ \\
\hline Young's modulus $(\mathrm{GPa})$ & $0.0517 \pm 0.00981$ & $0.0365 \pm 0.00771$ & $0.000594 \pm 0.000136$ & $0.000586 \pm 0.0000926$ \\
Density $\left(\mathrm{g} / \mathrm{cm}^{3}\right)$ & $0.901 \pm 0.08$ & $0.699 \pm 0.09$ & $0.509 \pm 0.07$ & $0.420 \pm 0.08$ \\
\hline
\end{tabular}

\subsection{Obtaining Granules from Waste Tanning Shavings}

The developed methods of processing shavings make it possible to produce agglomerates with proper dimensions, a shape close to a sphere, and relatively high mechanical strength. It is also possible to use other waste materials, such as for example fine-grained 
gypsum, which together with a drying process ensures granules that are dry on the outside, that form a non-lumping deposit loose enough for the produced agglomerates to be transferred to subsequent technological operations [58,59].

Figure 2 shows a comparison of optimum grain-size compositions of agglomerates produced in line with the methods described above (Methods 1-3; two examples per each method). The developed methods show it is possible to produce agglomerates on the basis of waste shavings with varying grain-size composition (with varying granules diameter in relation to the given intended purpose). The best quality granules were obtained from shavings previously mixed with a water glass solution (Methods 2 and 3).

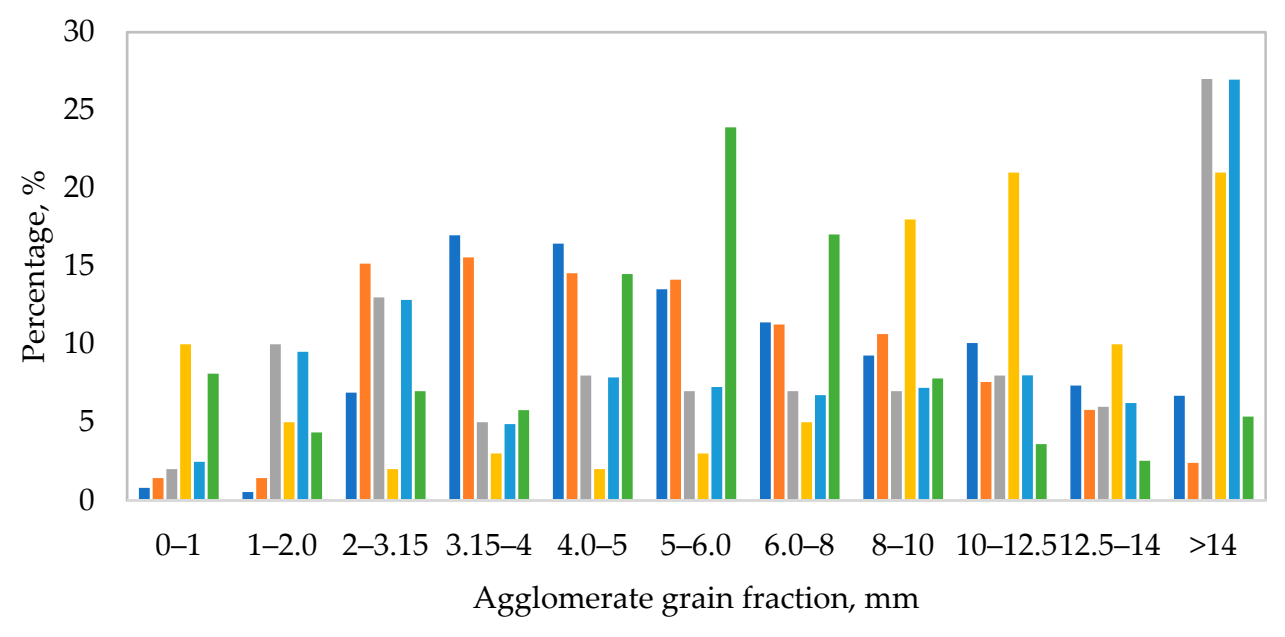

$\square$ Method $1 \square$ Method 1' Method $2 \square$ Method 2' $\square$ Method $3 \square$ Method 3'

Figure 2. Granulate grain-size (Methods 1, 2, 3; two examples per each method).

\subsection{Seed Coatings Based on Collagen Preparations}

In view of the nutrition aspect of the plant germination and growth stage, the determining parameter of the used collagen preparations was their amino acid composition. The amino acid analysis (a 6-aminoquinolyl-N-hydroxysuccinimidyl carbamate (AQC) derivatization procedure was applied) indicated the presence of 18 amino acids (aspartate, serine, glutamine, histidine, glycine, arginine, threonine, alanine, proline, cysteine, tyrosine, valine, lysine, methionine, isoleucine, leucine, phenylalanine, and hydroxyproline) in the collagen samples; glycine, alanine, proline, and hydroxyproline were the most abundant amino acids $[64,65]$.

The use of a disc granulator made it possible to form coatings using collagen preparations for seeds of varying dimensions and shapes $[61,63]$. As a result of the tests, complete, enclosed, spherical, and durable coatings of legumes and rape seeds were formed, increasing their resistance to drought and facilitating plant growth though improving moisture conditions at the germination stage. The length of seedlings for selected seeds and the developed compositions of coatings are shown in Table 5.

An analysis of seedling length showed the effectiveness of collagen preparations in terms of agricultural science as biostimulants [66-68], ensuring environmentally friendly crop management, as they enhanced the quality of crops while decreasing chemical inputs. What was also important was their advantage over the model preparation (yellow dextrin and polyvinyl alcohol [69]) and other selected production residues, i.e., solutions of molasses. In addition, the compatibility of the produced coating makes it possible to use a layer of fungicides and zoocides, protecting the seeds against pathogens and pests. 
Table 5. Average seedling length for seeds coated with a different composition.

\begin{tabular}{ccc}
\hline Composition of Coat & Seeds & Average Seedling Length for a Coated Seed, mm \\
\hline collagen hydrolysate, soot & pea & $35.58 \pm 1.55$ after 10 days following sowing \\
solutions of molasses, soot & pea & $33.28 \pm 1.89$ after 10 days following sowing \\
collow dextrin and polyvinyl alcohol, soot & pea & $34.46 \pm 0.88$ after 10 days following sowing \\
collagen hydrolysate & rape & $12.1 \pm 1.51$ after 7 days following sowing \\
yellow dextrin and polyvinyl alcohol & rape & $11.56 \pm 1.66$ after 7 days following sowing \\
collagen hydrolysate, dolomite & rape & $11.45 \pm 1.15$ after 7 days following sowing \\
yellow dextrin and polyvinyl alcohol, dolomite & rape & $11.075 \pm 1.25$ after 7 days following sowing \\
collagen hydrolysate, dolomite, peat & rape & $11.75 \pm 0.35$ after 7 days following sowing \\
yellow dextrin and polyvinyl alcohol, dolomite, peat & rape & $10.7 \pm 0.54$ after 7 days following sowing \\
\hline
\end{tabular}

\section{Discussion}

Tanning shavings are a biological material of a diverse, mixed, and heterogeneous nature, with the possible presence of hazardous substances. The risk of using tanning shavings as a renewable raw material should be assessed in terms of the presence of hazardous substances. Nevertheless, tanning shavings can be successfully processed and used in technological and chemical applications. Furthermore, the authors of paper [70] developed a new formula for applications in tanning processes, which reduces volatile organic compounds. Finishing processes are one of the main sources of VOCs in the tanning industry. The volatile organic compounds released by leather materials in different conditions are important for identifying the specific odor of natural leather products [71].

The obtained results show possible wide applications of composite materials produced from tanning shavings. The legitimacy of the proposed solution was also confirmed by the body of literature. There were many examples of solutions for solid waste management in tanneries $[61,72,73]$. In the building sector, solutions include new acoustic panels based on leather shavings (wet-white) and gypsum, cement, and latex, according to [74]. The research showed sound absorption coefficients of these materials close to those of cork panels or carpets. Moreover, the authors of the paper identified that the calorific values of waste dried hair and leather shavings were found to offer a competitive value in comparison with the biomass products used at present, e.g., wood pellets. Other uses included composite structures made of leather fibers (leather shavings) and cement and leather fibers with rubber powder derived from rubber waste [75]. Leather fibers added to cement mortar panels play an important role in construction due to both their mechanical strength and insulation properties. Waste was introduced as a filler, a powder, or as aggregates in concrete mix, with economic, energy, and environmental benefits [75]. The relevant body of literature gives examples of using leather waste in composite and biocomposite materials that are highly biocompatible, with excellent mechanical properties: biocomposite layers of silica from coatings of silica sols mixed with protein hydrolysate in water/dioxane [76], collagen hydrolysate used as a wall material with chitosan in microencapsulation [77], and other composites [78-83]. Further examples include wrapping and packaging materials, such as hydrogels produced with protein hydrolysate with dialdehyde starch, applicable as biodegradable packaging materials for pharmaceutical products, food, and cosmetics [84], paperboard consisting of mixed newspapers and newspapers and leather waste of long fibers [1], paper sheets (with improved properties: water resistance, air permeability, and thermal stability) with multistage disintegration leather shavings [85].

About $60 \%$ of industrial chemical products are produced in a granular form [86-89]. The agglomerate obtained from disc granulation is mechanically stable, durable, as well as easy to transport and store. Granulated materials produced using the developed methods (especially in line with method 1, $1^{\prime}, 3^{\prime}$ ) contained a large share of 2-6 mm fraction grains that have the highest application potential in terms of their use in other processing applications (e.g., composite materials).

The strength parameters of the granules were strongly influenced by the application of a water glass solution. This dependence was also obtained in a paper concerning the 
disc granulation of fly ash and a few percent addition of a filler (bentonite) [90]. Another study investigated the possibility of using a sodium silicate solution in a drum granulation process for biowaste granules [91]. Lower values (compared to tanning shaving granules) of the average destroying force were obtained for carbonation lime mud granulates in which a water solution of molasses was used [55]. The potential application area of the produced granulate involves the production of composite materials based on comminuted collagen fibers, agricultural technology, and as fillers/additives in construction and road construction.

The developed methods of seed pelleting make it possible to produce multicomponent and multilayer coatings with a wide spectrum of activity. Equally important are the type and amount of additives used as well as the sequence of layers. Studies [92-95] indicated that the growth and primary functioning of plants can be improved by coating seeds with waste-derived materials. Plants can also take up and absorb these amino acids, which sometimes constitute better nitrogen sources than synthetic fertilizers. Furthermore, microelements chelated with hydrolyzed proteins are more easily absorbed by both plant and animal organisms. The literature mentions examples of the use of collagen or collagen and keratin (recovered from the leather industry by-products) preparations as biofertilizers and foliar fertilizers $[96,97]$. It is possible to use materials recovered from leather waste in cosmetics (e.g., creams), biomedical products (e.g., burn dressings and implant coverings), dietary supplements, and veterinary and feed proteins.

The process of removing chromium from leather waste is based on its contact with solutions of salts, with the addition of acids, and/or anhydrides of acids (acid hydrolysis or alkaline agents, alkaline hydrolysis). There are also combined methods, such as enzymatic and acid hydrolysis. The hydrolysis of leather shavings resulted in a liquid and solid substance with potential applications [98]. The chemical and biochemical method confirmed that the efficiency of protein extraction was $60 \%$ and $80 \%$, respectively [99]. Collagenrich waste can be recycled using methods based on microorganism and enzymatic treatment [100]. There are many dechroming methods that are environmentally friendly and extract native collagen with high molecular weight and yield from chromium-containing leather waste [101]. The economic aspect is also important in the developed methods.

Work is currently underway at the institute in terms of using tanning shavings as a filler in materials intended for the prefabrication of building partitions, agglomerated using secondary raw materials, including waste wood and the textile industry waste. As a result of adding shavings (in the amount of $10 \%, 20 \%$, and $30 \%$ ) in wood-like boards pressed under pressure and at a temperature $\left(180^{\circ} \mathrm{C}\right)$, microbiological resistance of the new materials was obtained (in relation to boards without the filler).

\section{Conclusions}

The test of the shavings composition proves their potential reuse in multiple applications in a closed cycle. Leather waste can be processed at an industrial scale to produce value-added products as well as through operations and unit processes (especially those dedicated for the construction, packaging, and agricultural sectors).

The solutions listed above are the confirmed possibilities of using tanning waste in the building sector in accordance with the circular economy model. The properties of the obtained composites can be individually shaped according to the demand and application, through the selection of process parameters. The application of unit processes (such as sieving, granulation, and mixing) in terms of using and processing leather waste (animalderived biomass) makes it possible to develop new environmentally friendly products that can be composted and that are nontoxic to the ecosystem.

The developed and tested method of waste tanning shavings disc granulation may solve the problem of their processing and make it possible to obtain a durable, mechanically stable, and easy to transport and store semi-finished product. Processing solid leather waste into new raw materials increases the life cycle of the material and reduces its negative environmental impact. Furthermore, considering the limited natural resources, efforts 
aimed at recovering valuable components from waste materials, while optimizing costs, should be intensified.

\section{Patents}

There are patents and applications resulting from the work reported in this manuscript:

- Method for producing agglomerate from the tanning shavings, Application number P.425268, Exclusive right number Pat.236818

- Method for producing agglomerate from the tanning shavings, Application number P.425277, Exclusive right number Pat.236819

- Method for producing agglomerate from the tanning shavings, Application number P.425287, Exclusive right number Pat.238881

- Method for producing agglomerate from the tanning shavings, Application number P.425288, Exclusive right number Pat.238882

- Method of producing an agglomerate from waste tanning shavings, Application number (P.431100, P.431101, P.431099, P.431102)

Funding: This research was funded by the National Science Centre, grant number DEC-2017/01/X/ST8/ 01045 titled "Specification of an optimum composition of a composite of collagen fibers originating from leather industry waste and mineral additives". This research was funded by the National Centre for Research and Development grant number No. 6/RUSPLUS-INNO/2016 titled "New treatment based on collagen hydrolysates for increasing the drought resistance of Leguminosarum seedlings" and grant number No. EUREKA/COLL-RAPE/5/2017 titled "New treatment for rape seeds based on collagen hydrolysates in order to increase the drought resistance of rape seedlings". This research was funded by the state budget, subsidy of the President of Łukasiewicz Research Network, grant number 1/Ł- ITD/CŁ/2021 MATRECBUD titled "Materials for the prefabrication of building partitions, agglomerated using secondary raw materials, including waste wood, the textile industry waste, and the leather industry waste".

Institutional Review Board Statement: Not applicable.

Informed Consent Statement: Not applicable.

Data Availability Statement: Not applicable.

Conflicts of Interest: The author declares no conflict of interest.

\section{References}

1. Bufalo, G.; Florio, C.; Cinelli, G.; Lopez, F.; Cuomo, F.; Ambrosone, L. Principles of minimal wrecking and maximum separation of solid waste to innovate tanning industries and reduce their environmental impact: The case of paperboard manufacture. $J$. Clean. Prod. 2018, 174, 324-332. [CrossRef]

2. Sandhya, K.V.; Abinandan, S.; Vedaraman, N.; Velappan, K.C. Extraction of fleshing oil from waste limed fleshings and biodiesel production. Waste Manag. 2016, 48, 638-643. [CrossRef]

3. Kanagaraj, J.; Velappan, K.C.; Babu, N.K.C.; Sadulla, S. Solid Wastes Generation in the Leather Industry and Its Utilization for Cleaner Environment. J. Sci. Hemind Res. 2006, 37, 541-548. [CrossRef]

4. Agustini, C.B.; Spier, F.; da Costa, M.; Gutterres, M. Biogas production for anaerobic co-digestion of tannery solid wastes under presence and absence of the tanning agent. Resour. Conserv. Recycl. 2018, 130, 51-59. [CrossRef]

5. Getahun, E. Experimental Investigation and Characterization of Biodiesel Production from Leather Industry Fleshing Wastes. Int. J. Renew. Sustain. Energy 2013, 2, 120-129. [CrossRef]

6. Šánek, L.; Pecha, J.; Kolomazník, K.; Bařinová, M. Biodiesel production from tannery fleshings: Feedstock pretreatment and process modeling. Fuel 2015, 148, 16-24. [CrossRef]

7. Amdouni, S.; Trabelsi, A.B.H.; Elasmi, A.M.; Chagtmi, R.; Haddad, K.; Jamaaoui, F.; Khedhira, H.; Chérif, C. Tannery fleshing wastes conversion into high value-added biofuels and biochars using pyrolysis process. Fuel 2021, 294, 120423. [CrossRef]

8. Huang, X.; Yu, F.; Peng, Q.; Huang, Y. Superb adsorption capacity of biochar derived from leather shavings for Congo red. RSC Adv. 2018, 8, 29781-29788. [CrossRef]

9. Louarrat, M.; Rahman, A.N.; Bacaoui, A.; Yaacoubi, A. Removal of Chromium Cr(Vi) of Tanning Effluent with Activated Carbon from Tannery Solid Wastes. Am. J. Phys. Chem. 2017, 6, 103. [CrossRef]

10. Pinheiro, N.S.C.; Perez-Lopez, O.W.; Gutterres, M. Solid leather wastes as adsorbents for cationic and anionic dye removal. Environ. Technol. 2020, 2020, 1-9. [CrossRef] [PubMed] 
11. Arcibar-Orozco, J.A.; Barajas-Elias, B.S.; Caballero-Briones, F.; Nielsen, L.; Rangel-Mendez, J.R. Hybrid Carbon Nanochromium Composites Prepared from Chrome-Tanned Leather Shavings for Dye Adsorption. Water Air Soil Pollut. 2019, 230, 142. [CrossRef]

12. Romanowska-Duda, Z.; Szufa, S.; Grzesik, M.; Piotrowski, K.; Janas, R. The Promotive Effect of Cyanobacteria and Chlorella sp. Foliar Biofertilization on Growth and Metabolic Activities of Willow (Salix viminalis L.) Plants as Feedstock Production, Solid Biofuel and Biochar as C Carrier for Fertilizers via Torrefaction Process. Energies 2021, 14, 5262. [CrossRef]

13. Marczak-Grzesik, M.; Budzyń, S.; Tora, B.; Szufa, S.; Kogut, K.; Burmistrz, P. Low-Cost Organic Adsorbents for Elemental Mercury Removal from Lignite Flue Gas. Energies 2021, 14, 2174. [CrossRef]

14. Wielgosiński, G.; Czerwińska, J.; Szufa, S. Municipal Solid Waste Mass Balance as a Tool for Calculation of the Possibility of Implementing the Circular Economy Concept. Energies 2021, 14, 1811. [CrossRef]

15. Siuda, R.; Kwiatek, J.; Szufa, S.; Obraniak, A.; Piersa, P.; Adrian, L.; Modrzewski, R.; Ławińska, K.; Siczek, K.; Olejnik, T.P. Industrial Verification and Research Development of Lime-Gypsum Fertilizer Granulation Method. Minerals 2021, 11, 119. [CrossRef]

16. Stelmach, J.; Kuncewicz, C.; Szufa, S.; Jirout, T.; Rieger, F. The Influence of Hydrodynamic Changes in a System with a Pitched Blade Turbine on Mixing Power. Processes 2021, 9, 68. [CrossRef]

17. Gil, R.; Ruiz, B.; Lozano, M.; Martin, M.J.; Fuente, E. VOCs removal by adsorption onto activated carbons from biocollagenic wastes of vegetable tanning. Chem. Eng. J. 2014, 245, 80-88. [CrossRef]

18. Gammoun, A.; Tahiri, S.; Albizane, A.; Azzi, M.; Moros, J.; Garrigues, S.; de la Guardia, M. Separation of motor oils, oily wastes and hydrocarbons from contaminated water by sorption on chrome shavings. J. Hazard. Mater. 2007, 145, 148-153. [CrossRef]

19. Kluska, J.; Ochnio, M.; Kardaś, D.; Heda, Ł. The influence of temperature on the physicochemical properties of products of pyrolysis of leather-tannery waste. Waste Manag. 2019, 88, 248-256. [CrossRef]

20. Guo, L.; Zhao, J.; Zhao, L.; Tang, Y.; Zhou, J.; Shi, B. Persulfate activation by Cr2O3/BC derived from chrome shavings for antibiotics degradation. Chem. Eng. J. 2021, 420, 127698. [CrossRef]

21. Fang, C.; Jiang, X.; Lv, G.; Yan, J.; Lin, X.; Song, H.; Cao, J. Pyrolysis characteristics and Cr speciation of chrome-tanned leather shavings: Influence of pyrolysis temperature. Energy Sources Part A Recover. Util. Environ. Eff. 2018, 41, 881-891. [CrossRef]

22. Liu, J.; Luo, L.; Zhang, Z.; Hu, Y.; Wang, F.; Li, X.; Tang, K. A combined kinetic study on the pyrolysis of chrome shavings by thermogravimetry. Carbon Resour. Convers. 2020, 3, 156-163. [CrossRef]

23. Szufa, S.; Piersa, P.; Adrian, Ł.; Czerwińska, J.; Lewandowski, A.; Lewandowska, W.; Sielski, J.; Dzikuć, M.; Wróbel, M.; Jewiarz, M.; et al. Sustainable Drying and Torrefaction Processes of Miscanthus for Use as a Pelletized Solid Biofuel and Biocarbon-Carrier for Fertilizers. Molecules 2021, 26, 1014. [CrossRef]

24. Szufa, S. Use of superheated steam in the process of biomass torrefaction. Przemyst Chem. 2020, 99, 1797-1801. (In Polish) [CrossRef]

25. Kryszak, D.; Bartoszewicz, A.; Szufa, S.; Piersa, P.; Obraniak, A.; Olejnik, T.P. Modeling of Transport of Loose Products with the Use of the Non-Grid Method of Discrete Elements (DEM). Processes 2020, 8, 1489. [CrossRef]

26. Szufa, S.; Adrian, Ł.; Piersa, P.; Romanowska-Duda, Z.; Grzesik, M.; Cebula, A.; Kowalczyk, S. Experimental studies on energy crops torrefaction process using batch reactor to estimate torrefaction temperature and residence time. In Renewable Energy Sources: Engineering, Technology, Innovation. Springer Proceedings in Energy; Mudryk, K., Werle, S., Eds.; Springer Proceedings in Energy; Springer: Berlin/Heidelberg, Germany, 2018; pp. 365-373. [CrossRef]

27. Gomes, C.S.; Repke, J.; Meyer, M. The effect of various pre-treatment methods of chromium leather shavings in continuous biogas production. Eng. Life Sci. 2019, 20, 79-89. [CrossRef]

28. Gomes, C.S.; Repke, J.-U.; Meyer, M. Investigation of different pre-treatments of chromium leather shavings to improve biogas production. J. Leather Sci. Eng. 2020, 2, 1-14. [CrossRef]

29. Agustini, C.B.; Meyer, M.; Da Costa, M.; Gutterres, M. Biogas from anaerobic co-digestion of chrome and vegetable tannery solid waste mixture: Influence of the tanning agent and thermal pretreatment. Process. Saf. Environ. Prot. 2018, 118, 24-31. [CrossRef]

30. Pietrelli, L.; Ferro, S.; Reverberi, A.P.; Vocciante, M. Removal and recovery of heavy metals from tannery sludge subjected to plasma pyro-gasification process. J. Clean. Prod. 2020, 273, 123166. [CrossRef]

31. Ferreira, S.D.; Junges, J.; Scopel, B.; Manera, C.; Osório, E.; Lazzarotto, I.P.; Godinho, M. Steam Gasification of Biochar Derived from the Pyrolysis of Chrome-Tanned Leather Shavings. Chem. Eng. Technol. 2019, 42, 2530-2538. [CrossRef]

32. Olejnik, T. Analysis of the breakage rate function for selected process parameters in quartzite milling. Chem. Process. Eng. 2012, 33, 117-129. [CrossRef]

33. Heim, A.; Olejnik, T.P.; Pawlak, A. Using statistical moments to describe grinding in a ball mill for industrial-scale process. Chem. Eng. Process. Process. Intensif. 2005, 44, 263-266. [CrossRef]

34. Olejnik, T.P. Milling kinetics of chosen rock materials under dry conditions considering strength and statistical properties of bed. Physicochem. Probl. Miner. Process. 2011, 46, 145-154.

35. Sharafa, S.A.A.; Gasmeleed, G.A.; Musa, A.E. Reduction of hexavalent chromium from chrome shavings. International J. Adv. Ind. Eng. 2013, 1, 24-27.

36. Sreeram, K.; Rao, J.; Nair, B. Chromium (III) Pigments: Use of leather wastes as alternative starting material. J. Am. Leather Chem. Assoc. 2011, 106, 219-225.

37. Zehra, B.; Nawaz, H.B.; Solangi, B.A.; Nadeem, U. Extraction of Protein from Chrome Shavings, Modification with Acrylic Monomers and Further Re-Utilization in Leather Processing. Am. Sci. Res. J. Eng. Technol. Sci. 2019, 52, 98-104. 
38. Kubilius, K.; Valeikiene, V.; Valeika, V. Collagen hydrolysate from chromed shavings for leather finish. In Proceedings of the 8th International Conference on Advanced Materials and Systems, Bucharest, Romania, 1-3 October 2020; Leather and Footwear Research Institute (INCDTP-ICPI): Bucharest, Romania; pp. 399-402.

39. Kanagaraj, J.; Panda, R.C.; Prasanna, R. Sustainable Chrome Tanning System Using Protein Based Product Developed from Leather Waste: Wealth from Waste. Res. Sq. 2021, 1, 1-30. [CrossRef]

40. Oruko, R.; Selvarajan, R.; Ogola, H.; Edokpayi, J.; Odiyo, J.O. Contemporary and future direction of chromium tanning and management in sub Saharan Africa tanneries. Process. Saf. Environ. Prot. 2020, 133, 369-386. [CrossRef]

41. Kocurek, P.; Kolomazník, K.; Bařinová, M.; Hendrych, J. Total control of chromium in tanneries-thermal decomposition of filtration cake from enzymatic hydrolysis of chrome shavings. Waste Manag. Res. 2017, 35, 444-449. [CrossRef]

42. Long, H.; Huang, X.; Liao, Y.; Ding, J. Recovery of Cr (VI) from tannery sludge and chrome-tanned leather shavings by $\mathrm{Na}_{2} \mathrm{CO} 3$ segmented calcination. J. Environ. Chem. Eng. 2021, 9, 105026. [CrossRef]

43. Wu, C.; Zhang, W.; Liao, X.; Zeng, Y.; Shi, B. Transposition of Chrome Tanning in Leather Making. J. Am. Leather Chem. Assoc. 2014, 109, 176-183.

44. China, C.R.; Maguta, M.M.; Nyandoro, S.S.; Hilonga, A.; Kanth, S.V.; Njau, K.N. Alternative tanning technologies and their suitability in curbing environmental pollution from the leather industry: A comprehensive review. Chemosphere 2020, 254, 126804. [CrossRef]

45. Zuriaga-Agustí, E.; Galiana-Aleixandre, M.; Bes-Piá, A.; Mendoza-Roca, J.-A.; Risueño-Puchades, V.; Segarra, V. Pollution reduction in an eco-friendly chrome-free tanning and evaluation of the biodegradation by composting of the tanned leather wastes. J. Clean. Prod. 2015, 87, 874-881. [CrossRef]

46. Modrzewski, R.; Wodzinski, P. Grained material classification on a double frequency screen. Physicochem. Probl. Miner. Process. 2011, 46, 5-12.

47. Modrzewski, R.; Wodzinski, P. The results of process investigations of a double frequency screen. Physicochem. Probl. Miner. Process. 2010, 44, 169-178.

48. Lawinska, K.; Serweta, W.; Modrzewski, R. Studies on water absorptivity and desorptivity of tannery shavings-based composites with mineral additives. Przem. Chem. 2019, 98, 106-109. [CrossRef]

49. Katarzyna, L.; Remigiusz, M.; Piotr, W. Mathematical and empirical description of screen blocking. Granul. Matter 2016, 18, 13. [CrossRef]

50. Lawinska, K.; Modrzewski, R. Analysis of sieve holes blocking in a vibrating screen and a rotary and drum screen. Physicochem. Probl. Miner. Process. 2017, 53, 812-828. [CrossRef]

51. Lawinska, K.E.; Wodzinski, P.; Modrzewski, R. A method for determining sieve holes blocking degree. Physicochem. Probl. Miner. Process. 2015, 51, 15-22. [CrossRef]

52. Sieczyńska, K. Stężenia wybranych metali w produktach kosmetycznych stosowanych do makijażu oczu. Przemyst Chem. 2020, 1, 131-134. [CrossRef]

53. Ławińska, K.; Modrzewski, R.; Serweta, W. Tannery Shavings and Mineral Additives as a Basis of New Composite Materials. Fibres Text. East. Eur. 2019, 27, 130-139. [CrossRef]

54. Ławińska, K.; Serweta, W.; Modrzewski, R. Qualitative Evaluation of the Possible Application of Collagen Fibres: Composite Materials with Mineral Fillers as Insoles for Healthy Footwear. Fibres Text. East. Eur. 2018, 26, 81-85. [CrossRef]

55. Ławińska, K.; Szufa, S.; Obraniak, A.; Olejnik, T.; Siuda, R.; Kwiatek, J.; Ogrodowczyk, D. Disc Granulation Process of Carbonation Lime Mud as a Method of Post-Production Waste Management. Energies 2020, 13, 3419. [CrossRef]

56. Obraniak, A.; Orczykowska, M.; Olejnik, T.P. The effects of viscoelastic properties of the wetting liquid on the kinetics of the disc granulation process. Powder Technol. 2019, 342, 328-334. [CrossRef]

57. Obraniak, A.; Lawinska, K. Spectrophotometric analysis of disintegration mechanisms (abrasion and crushing) of agglomerates during the disc granulation of dolomite. Granul. Matter 2017, 20, 7. [CrossRef]

58. Ławińska, K.; Modrzewski, R.; Obraniak, A. Comparison of granulation methods for tannery shavings. Fibres Text. East. Eur. 2020, 28, 119-123. [CrossRef]

59. Ławińska, K.; Obraniak, A.; Modrzewski, R. Granulation Process of Waste Tanning Shavings. Fibres Text. East. Eur. 2019, 27, 107-110. [CrossRef]

60. Ławińska, K.; Szufa, S.; Modrzewski, R.; Obraniak, A.; Wężyk, T.; Rostocki, A.; Olejnik, T.P. Obtaining Granules from Waste Tannery Shavings and Mineral Additives by Wet Pulp Granulation. Molecules 2020, 25, 5419. [CrossRef] [PubMed]

61. Ławińska, K.; Lasoń-Rydel, M.; Gendaszewska, D.; Grzesiak, E.; Sieczyńska, K.; Gaidau, C.; Epure, D.-G.; Obraniak, A. Coating of Seeds with Collagen Hydrolysates from Leather Waste. Fibres Text. East. Eur. 2019, 27, 59-64. [CrossRef]

62. Pati, A.; Chaudhary, R.; Subramani, S. A review on management of chrome-tanned leather shavings: A holistic paradigm to combat the environmental issues. Environ. Sci. Pollut. Res. 2014, 21, 11266-11282. [CrossRef]

63. Lawinska, K. Zagospodarowanie odpadów garbarskich w nasiennictwie. Przemyst Chem. 2017, 1, 162-165. [CrossRef]

64. Lawinska, K. Otoczkowanie nasion strączkowych hydrolizatami kolagenu z odpadów garbarskich. Przemyst Chem. 2017, 1, 71-74. [CrossRef]

65. Gendaszewska, D.; Lasoń-Rydel, M.; Ławińska, K.; Grzesiak, E.; Pipiak, P. Characteristics of collagen preparations from leather wastes by the high pressure liquid chromatography method. Fibres Text. East. Eur. 2021, 29, 75-79. [CrossRef] 
66. Szufa, S.; Dzikuć, M.; Adrian, Ł.; Piersa, P.; Romanowska-Duda, Z.; Lewandowska, W.; Marcza, M.; Błaszczuk, A.; Piwowar, A. Torrefaction of oat straw to use as solid biofuel, an additive to organic fertilizers for agriculture purposes and activated carbon-TGA analysis, kinetics. E3S Web Conf. 2020, 154, 02004. [CrossRef]

67. Szufa, S.; Piersa, P.; Adrian, Ł.; Sielski, J.; Grzesik, M.; Romanowska-Duda, Z.; Piotrowski, K.; Lewandowska, W. Acquisition of Torrefied Biomass from Jerusalem Artichoke Grown in a Closed Circular System Using Biogas Plant Waste. Molecules 2020, 25, 3862. [CrossRef] [PubMed]

68. Szufa, S.; Wielgosiński, G.; Piersa, P.; Czerwińska, J.; Dzikuć, M.; Adrian, Ł.; Lewandowska, W.; Marczak, M. Torrefaction of Straw from Oats and Maize for Use as a Fuel and Additive to Organic Fertilizers-TGA Analysis, Kinetics as Products for Agricultural Purposes. Energies 2020, 13, 2064. [CrossRef]

69. Domoradzki, M.; Korpal, W. Germination analysis for coated radish seeds, carried out using four selected bed types. Agric. Eng. 2005, 2, 27-33.

70. Cuadros, R.; Solà, A.; Ollé, I.; Otero, L.; Bacardit, A. Reducing the use of volatile organic compoundsin the leather industry. J. Soc. Leather Technol. Chem. 2016, 100, 1-7.

71. Stanca, M.; Gaidau, C.; Alexe, C.-A.; Stanculescu, I.; Vasilca, S.; Matei, A.; Simion, D.; Constantinescu, R.-R. Multifunctional Leather Surface Design by Using Carbon Nanotube-Based Composites. Materials 2021, 14, 3003. [CrossRef]

72. Parisi, M.; Nanni, A.; Colonna, M. Recycling of Chrome-Tanned Leather and Its Utilization as Polymeric Materials and in Polymer-Based Composites: A Review. Polymers 2021, 13, 429. [CrossRef]

73. Yang, J.; Li, S.; Jiang, H.; Su, C.; Shao, Y.; Gao, Y.; Li, J. Preparation of recycled graphite/expanded polystyrene by a facile solvent dissolution method. J. Mater. Sci. 2018, 54, 1197-1204. [CrossRef]

74. Vidaurre-Arbizu, M.; Pérez-Bou, S.; Zuazua-Ros, A.; Martín-Gómez, C. From the leather industry to building sector: Exploration of potential applications of discarded solid wastes. J. Clean. Prod. 2021, 291, 125960. [CrossRef]

75. Zainescu, G. Polymer Compositions from Leather Fibers (Leather Shavings) for Mortar in Constructions. In Proceedings of the 18th SGEM International Multidisciplinary Scientific GeoConference SGEM2018, Energy and Clean Technologies Stef92 Technology, Albena, Bulgaria, 2-8 July 2018; pp. 79-86.

76. Brasack, I.; Böttcher, H.; Hempel, U. Biocompatibility of Modified Silica-Protein Composite Layers. J. Sol-Gel Sci. Technol. 2000, 19, 479-482. [CrossRef]

77. Ocak, B.; Aslan, A.; Gulumser, G. Utilization of chromium-tanned leather solid wastes in microencapsulation. J. Am. Leather Chem. Assoc. 2011, 106, 232-238.

78. Ashokkumar, M.; Thanikaivelan, P.; Murali, R.; Chandrasekaran, B. Preparation and Characterization of Composite Sheets from Collagenous and Chromium-Collagen Complex Wastes Using Polyvinylpyrrolidone: Two Problems, One Solution. Waste Biomass-Valorization 2010, 1, 347-355. [CrossRef]

79. Liu, Y.; Wang, Q.; Li, L. Reuse of leather shavings as a reinforcing filler for poly (vinyl alcohol). J. Thermoplast. Compos. Mater. 2016, 29, 327-343. [CrossRef]

80. Ramamurthy, G.; Ramalingam, B.; Katheem, M.F.; Sastry, T.P.; Inbasekaran, S.; Thanveer, V.; Jayaramachandran, S.; Das, S.K.; Mandal, A.B. Total Elimination of Polluting Chrome Shavings, Chrome, and Dye Exhaust Liquors of Tannery by a Method Using Keratin Hydrolysate. ACS Sustain. Chem. Eng. 2015, 3, 1348-1358. [CrossRef]

81. Zhang, J.; Yan, Z.; Liu, X.; Zhang, Y.; Zou, H.; Le, Y.; Chen, J.-F. Conductive Skeleton-Heterostructure Composites Based on Chrome Shavings for Enhanced Electromagnetic Interference Shielding. ACS Appl. Mater. Interfaces 2020, 12, 53076-53087. [CrossRef] [PubMed]

82. Ding, C.; Zhang, M.; Dai, L.; Qi, Y.; Shi, R.; Yang, J. Fabrication and characterization of regenerated leather using chrome shavings raw material. J. Am. Leather Chem. Assoc. 2017, 112, 145-152.

83. Krummenauer, K.; Andrade, J.J.D.O. Incorporation of chromium-tanned leather residue to asphalt micro-surface layer. Constr. Build. Mater. 2009, 23, 574-581. [CrossRef]

84. Langmaier, F.; Mokrejs, P.; Kolomaznik, K.; Mladek, M. Plasticizing collagen hydrolysate with glycerol and low-molecular weight poly(ethylene glycols). Thermochim. Acta 2008, 469, 52-58. [CrossRef]

85. Mohamed, O.A.; Kassem, N.F. Utilization of waste leather shavings as filler in paper making. J. Appl. Polym. Sci. 2010, 118, 1713-1719. [CrossRef]

86. Rodrigues, R.F.; Leite, S.R.; Santos, D.A.; Barrozo, M.A. Drum granulation of single super phosphate fertilizer: Effect of process variables and optimization. Powder Technol. 2017, 321, 251-258. [CrossRef]

87. Quatrini, E.; Li, X.; Mba, D.; Costantino, F. Fault Diagnosis of a Granulator Operating under Time-Varying Conditions Using Canonical Variate Analysis. Energies 2020, 13, 4427. [CrossRef]

88. Obidziński, S. Ocena właściwości fizyczno-chemicznych granulatów z surowców odpadowych przetwórstwa spożywczego pod katem ich zastosowania jako zanęty dla ryb. Przemyst Chem. 2021, 1, 90-93. [CrossRef]

89. Heim, A.; Obraniak, A.; Gluba, T. Effect of bed wetting rate on the bulk density of granulated products. Przem. Chem. 2008, 87, 154-157.

90. Obraniak, A.; Gluba, T.; Ławińska, K.; Derbiszewski, B. Minimisation of environmental efects related with storing fly ash from combustion of hard coal. Environ. Prot. Eng. 2018, 44, 177-189. [CrossRef]

91. Chen, H.; Mangwandi, C.; Rooney, D. Production of solid biofuel granules from drum granulation of bio-waste with silicate-based binders. Powder Technol. 2019, 354, 231-239. [CrossRef] 
92. Skwarek, M.; Wala, M.; Kołodziejek, J.; Sieczyńska, K.; Lasoń-Rydel, M.; Ławińska, K.; Obraniak, A. Seed Coating with Biowaste Materials and Biocides-Environment-Friendly Biostimulation or Threat? Agronomy 2021, 11, 1034. [CrossRef]

93. Skwarek, M.; Nawrocka, J.; Lason-Rydel, M.; Ławińska, K. Diversity of plant biostimulants in plant growth promotion and stress protection in crop and fibrous plants. Fibres Text. East. Eur. 2020, 28, 34-41. [CrossRef]

94. Jewiarz, M.; Wróbel, M.; Mudryk, K.; Szufa, S. Impact of the Drying Temperature and Grinding Technique on Biomass Grindability. Energies 2020, 13, 3392. [CrossRef]

95. Dzikuć, M.; Kuryło, P.; Dudziak, R.; Szufa, S.; Dzikuć, M.; Godzisz, K. Selected Aspects of Combustion Optimization of Coal in Power Plants. Energies 2020, 13, 2208. [CrossRef]

96. Gaidau, C.; Ghiga, M.; Stepan, E.; Lacatus, V.; Cirjaliumurgea, M.; Ionita, A.D.; Filipescu, L. Emulsified foliar fluids from waste leather hydrolysis products. In Proceedings of the Ceex Conference, Brasov, Romania, 27-29 July 2008; pp. 1-7.

97. Niculescu, M.-D.; Epure, D.-G.; Lason-Rydel, M.; Gaidau, C.; Gidea, M.; Enascuta, C. Biocomposites based on collagen and keratin with properties for agriculture and industrie applications. EuroBiotech J. 2019, 3, 160-166. [CrossRef]

98. Pahlawan, I.F.; Sutyasmi, S.; Griyanitasari, G. Hydrolysis of leather shavings waste for protein binder. In Proceedings of the IOP Conference Series: Earth and Environmental Science, Universitas Brawijaya, East Java, Indonesia, 18-20 September 2018; IOP Publishing: Bristol, UK, 2019; Volume 230, p. 012083. [CrossRef]

99. Pati, A.; Chaudhary, R.; Subramani, S. Biochemical method for extraction and reuse of protein and chromium from chrome leather shavings: A waste to wealth approach. J. Am. Leather Chem. Assoc. 2013, 108, 365-372.

100. Shanthi, C.; Banerjee, P.; Chandra Babu, N.; Rajakumar, G. Recovery and characterization of protein hydrolysate from chrome shavings by microbial degradation. J. Am. Leather Chem. Assoc. 2013, 108, 231-239.

101. Tian, Z.; Wang, Y.; Wang, H.; Zhang, K. Regeneration of native collagen from hazardous waste: Chrome-tanned leather shavings by acid method. Environ. Sci. Pollut. Res. 2020, 27, 31300-31310. [CrossRef] [PubMed] 